\title{
Secret Dissertations in the German Democratic Republic
}

\section{Wilhelm Bleek and Lothar Mertens}

\begin{abstract}
Early in 1995 the editorial boards of $C \& R L$ and its German counterpart, Zeitschrift für Bibliothekswesen und Bibliographie (ZfBB), agreed to exchange articles, each selecting, translating, and publishing a 1994 article from the other's publication. This year's choice - our first-is a piece that had been published as a follow-up to an article that had appeared in the ZfBB in 1992. C\&RL has decided to publish them both. ${ }^{1}$ Partly in order to convey the sense the originals give of research unfolding in a contemporary historical context, we are publishing them in the form in which they originally appeared (minus one table and the footnotes). The results are sketchier and more tentative than is normally the case in $C \& R L$-and in the ZfBB. But in their very incompleteness they give a sense of a process of discovery and revelation that tells a powerful story. Since the original publication of these articles, the authors have published a book on their research, as well as a bibliography listing the suppressed dissertations. ${ }^{2,3}$ The articles are clearly "different" from the usual $C \& R L$ fare, but that's also the point. It is our hope that they will not only provide insight into recent events in Germany, but that they might help stimulate research on the interactions, direct and indirect, open and covert, between political structures and the research enterprise in our own country and elsewhere.
\end{abstract}

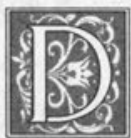

uring its 41 years of existence, the German Democratic Republic (GDR) harbored among its state secrets thousands of dissertations from East German institutions of higher education. Until now, one could only speculate as to their number and content. After 1988, and particularly since the GDR's democratic revolution in the fall of 1989 and the unification of Germany in October 1990, this secret area began to open up.
In a project supported by the German Research Foundation (Deutsche Forschungsgemeinschaft) the authors are currently investigating the classification of those dissertations designated as secret. This article focuses on their content and on the institutions at which they were written, as well as on the various levels of secrecy, and on their eventual release from classified status. The principal resources for this project were the library files at Berlin's Humboldt University Li-

Wilhelm Bleek and Lothar Mertens, Ruhr-Universität Bochum, Fakultät für Sozialwissenschaft, Sektion Politische Wissenschaft I, Universitätsstr. 150, 44780 Bochum, Germany. The editor wishes to thank John Cullars for translating the original German articles, and Heidi Hutchinson, Stephen Lehmann, and Sem C. Sutter for helping to prepare the manuscript for publication. 
brary, which list the dissertations and their secrecy levels. We have profited in addition from the gracious cooperation of Gottfried Rost of the Deutsche Bücherei Leipzig, who permitted access to the more than 6,800 dissertations recorded in the confidential catalogs and classified as "Official Use Only" (Level I) and "Confidential Official Matters" (Level II). In the following article we present the first results of our work with these sources from Leipzig.

\section{The Legal Background}

In compliance with the "Regulations for the Protection of Official Secrets" (1971), the GDR's Ministry of Higher Education began to remove dissertations from normal circulation in the early 1970 s. An additional set of "Regulations on the Archiving of University Publications with Official Secrets" (1977) designated the national library, the Deutsche Bücherei in Leipzig, as their repository. The use of these dissertations, even for scholarly purposes, was further impeded by a directive of October 4, 1977, from the Ministry of Higher Education, forbidding the Deutsche Bücherei to list them in its normal catalogs and bibliographies. Excluded from the German national bibliography and the annual index to German dissertations, they were listed only in special catalogs, and interested patrons could consult only that part of the cata$\log$ relevant to their topic. Further, citizens of the GDR had to present the authorization of the director of the Deutsche Bücherei; citizens of other countries needed the permission of the Minister of Higher Education. The accession catalogs of the Deutsche Bücherei listing the Level II dissertations were themselves treated as Level II.

In spite of the legal requirement to submit the dissertations no later than four weeks after completion to a central collection at the Deutsche Bücherei known as the Department of Special Research Literature, it often took several years for the universities to comply. This negligent and halting delivery had some strange consequences. For example, a 1977 dissertation from the Engineering College in Wismar, classified as Level II, was not listed in Leipzig until August 27, 1979, only for the classification to be canceled just one day later. The various university libraries would often involuntarily provoke forceful reminders of their depository obligations by sending letters to the central collection in Leipzig ordering that classifications be changed or canceled, only to find that, contrary to the requirements, they had never deposited the theses in the first place.

A governmental resolution of January 15,1987 , on the protection of state secrets ordered a review of the classification of all dissertations that were still restricted. Thereupon, until September 1988, numerous dissertations that had been secret were made publicly accessible, and the number of new dissertations requiring secret classification was also reduced. The last secret dissertation, entered on October 10, 1988, in the Level II accession book, shows once again how ambiguous and problematic the entire process of classification was. Although the principal volume of this dissertation from Ilmenau was officially accessible, its Appendix 3, approximately five pages, was classified Level II. This appendix contained three data processing programs described in the dissertation. These three FORTRAN programs contained 47, 55, and 100 lines respectively; they were simple compared to other freely available FORTRAN applications that often contained thousands of lines of programming, but they were apparently considered sufficiently significant to be designated Level II.

\section{Percentage of Dissertations Declared Secret}

The annual index of German dissertations (Jahresverzeichnis der Hochschulschriften) $(J V H)$ for the years 1978-1987 lists 34,383 dissertations from the various East Ger- 
man institutions of higher learning. The Deutsche Bücherei's accession catalogs for secret dissertations lists 6,824 dissertations for the same period that for reasons of secrecy could not be listed in the German national bibliography or in the index of dissertations. The combined total for all the doctoral theses produced in the GDR between 1978 and 1987 is thus $41,207$. The percentage of dissertations classified as Level I or II is 16.6 percent, more than one-eighth of all dissertations.

The classified dissertations from 1978 to 1987 were assigned to Levels I and II as illustrated in table 1.

After a few years, some of the Level II dissertations were either lowered to Level I or declassified entirely. Conversely, a dissertation classified as Level I in July 1986 at the Deutsche Bücherei was reclassified to Level II six months later. A study of suicides in the East German city of Görlitz, it was apparently considered too explosive by the authorities at the Medical Academy in Berlin.

\section{Differences Among Graduate Institutions}

An examination of secret dissertations grouped by the graduate institutions at which they were written reveals appreciable variations among different academies, universities, and colleges.

This disparity is equally true of the total number of secret dissertations at individual institutions and of the proportion of secret dissertations to the total produced at each institution. Of the 2,869 entries in the accessions catalog of the Deutsche Bücherei for dissertations classified as Level II, 2,778 (96.8\%) also list the degree-granting institution. The total number of Level II dissertations for individual institutions from 1978 to 1987 is
TABLE 1

SECRET DISSERTATIONS, LEVEL I AND LEVEL II, 1978-1987

Year Total Secret Diss. Level I Level II

$\begin{array}{llll}1978 & 399 & 235 & 164 \\ 1979 & 728 & 375 & 353 \\ 1980 & 621 & 279 & 342 \\ 1981 & 541 & 283 & 258 \\ 1982 & 766 & 289 & 477 \\ 1983 & 552 & 228 & 324 \\ 1984 & 713 & 263 & 450 \\ 1985 & 662 & 268 & 394 \\ 1986 & 1,143 & 400 & 743 \\ 1987 & 699 & 249 & 450 \\ \text { Total } & 6,824 & 2,869 & 3,955\end{array}$

(Source: Figures compiled from accession catalogs of the secret dissertations in the Deutsche Bücherei, Leipzig)

shown below in relation to the number of dissertations listed for those years in the annual dissertation index $(J V H)$.

As the data show in table 2, in addition to the differences in the total number of classified dissertations by institution, the percentage of Level II dissertations granted at each institution varies greatly. Clearly the total number of Level II dissertations in no way depends on the size of the institution and thus not on the total number of successfully defended dissertations. For instance, the University of Leipzig awarded over 1,000 more Ph.D.s than the University of Halle, but the number of secret dissertations was greater at Halle; its total number of dis-

\footnotetext{
A study of suicides in the East German city of Görlitz ... was apparently considered too explosive by the authorities at the Medical Academy in Berlin.
}

sertations was six times that of the Agricultural Academy, but its Level II dissertations numbered ten percent fewer. 
TABLE 2

LEVEL II DISSERTATIONS FROM SELECTED INSTITUTIONS, 1978-1987

\begin{tabular}{|c|c|c|c|c|}
\hline \multirow[t]{3}{*}{ Institution } & \multicolumn{4}{|c|}{ Dissertations } \\
\hline & \multirow[t]{2}{*}{$\begin{array}{l}\text { Total } \\
\text { No. }\end{array}$} & \multirow[t]{2}{*}{$\begin{array}{l}\text { Listed in diss. } \\
\text { index }\end{array}$} & \multicolumn{2}{|c|}{$\begin{array}{l}\text { Listed only in catalogs } \\
\text { of secret dissertations at } \\
\text { Deutsche Bücherei, Leipzig }\end{array}$} \\
\hline & & & No. & $\%$ \\
\hline Academy of Sciences & 1,431 & 1,326 & 105 & $7.3 \%$ \\
\hline Agricultural Academy & 597 & 377 & 220 & $36.9 \%$ \\
\hline Architectural Academy & 66 & 36 & 30 & $45.5 \%$ \\
\hline Medical Academy, Berlin & 2,009 & 1,965 & 44 & $2.2 \%$ \\
\hline Mining Academy, Freiberg & 751 & 599 & 152 & $20.2 \%$ \\
\hline Humboldt University, Berlin & 5,383 & 4,981 & 402 & $7.5 \%$ \\
\hline University of Greifswald & 1,202 & 1,123 & 79 & $6.6 \%$ \\
\hline University of Halle & 2,797 & 2,556 & 241 & $8.6 \%$ \\
\hline University of Jena & 1,903 & 1,804 & 99 & $5.2 \%$ \\
\hline University of Leipzig & 3,922 & 3,722 & 200 & $5.1 \%$ \\
\hline University of Rostock & 1,990 & 1,875 & 115 & $5.8 \%$ \\
\hline College of Economics, Berlin & 726 & 440 & 286 & $39.4 \%$ \\
\hline Commercial College, Leipzig & 242 & 175 & 67 & $27.7 \%$ \\
\hline
\end{tabular}

(Source: Figures compiled from Jahresverzeichnis der Hochschulschriften (German dissertation index), 1978-1987 and accession catalogs of secret dissertations in the Deutsche Bücherei, Leipzig)

*See Table 7 for updated figures on some institutions.

The Architectural Academy (Bauakademie) and the Institute for Economics in Berlin pursued the classification of dissertations as "secret" with particular zeal. The fact that economic research seemed to be especially worthy of protection is also shown by the figures from the Commercial College in Leipzig. Especially striking is the disproportion between the number of theses listed in the annual index of dissertations and the number of secret dissertations from the College of Economics in Berlin between 1978 and 1980.

In many cases, the university and departmental classification of dissertations cannot be explained solely by the need for state secrecy based on their content. One must also consider the various authorities and experts in the decision chain, as well as the particular institutional politics regarding secret dissertations. These 
discrepancies are documented in tables 3 to 5 , which compare the numbers of secret dissertations by type of institution (technical universities, engineering schools, and teachers colleges).

In addition to the technical universities in Dresden and Magdeburg (full universities since 1985, technical colleges before that) and the technical colleges in Ilmenau, Karl-Marx-Stadt, and LeunaMerseburg, table 3 includes the Transportation College, Dresden. Surprisingly, in both absolute numbers as well as percentages, the greatest number of secret dissertations is not from the technical universities in Dresden and Magdeburg, but from the three technical colleges. It is noteworthy that the earliest Level II clas- sification for Magdeburg is from as late as 1982, and that the first for Dresden is 1983.

The results from the engineering schools (see table 4) also illustrate the lack of rigor in the assignment of the secret classifications. The explanation for the comparatively high percentage for BerlinWartenberg and Mittweida may lie, perhaps, in the desire of these small schools to emphasize their significance and "exclusivity" through a large number of secret works.

Unlike the technical and engineering schools, the teachers colleges did not produce dissertations relevant to state security or the economy (see table 5). Their proportion of classified theses, not sur-

TABLE 3

SECRET DISSERTATIONS FROM SELECTED TECHNICAL SCHOOLS, 1978-1987

Institution

Dissertations

\begin{tabular}{ccc}
\hline $\begin{array}{c}\text { Total } \\
\text { No. }\end{array}$ & $\begin{array}{c}\text { Listed in diss. } \\
\text { index }\end{array}$ & $\begin{array}{c}\text { Listed only in catalogs } \\
\text { of secret dissertations at } \\
\text { Deutsche Bücherei, Leipzig }\end{array}$ \\
\cline { 2 - 3 } & No. & $\%$
\end{tabular}

Universities

\begin{tabular}{lcccc} 
Dresden & 3,101 & 3,052 & 49 & $1.6 \%$ \\
Magdeburg & 789 & 751 & 38 & $4.8 \%$ \\
Colleges & 683 & 588 & 95 & $13.9 \%$ \\
Ilmenau & 1,250 & 1,029 & 221 & $17.7 \%$ \\
Karl-Marx-Stadt & 639 & 512 & 127 & $19.9 \%$ \\
Leuna-Merseburg & & & 38 & $8.2 \%$ \\
Other & 464 & 426 & & \\
\hline
\end{tabular}

(Source: Figures compiled from Jahresverzeichnis der Hochschulschriften (German dissertation index), 1978-1987 and accession catalogs of secret dissertations in the Deutsche Bücherei, Leipzig)

*See Table 7 for updated figures. 
TABLE 4

SECRET DISSERTATIONS FROM SELECTED ENGINEERING COLLEGES, 1978-1987

\begin{tabular}{|c|c|c|c|c|}
\hline \multirow[t]{3}{*}{ Institution } & \multicolumn{4}{|c|}{ Dissertations } \\
\hline & \multirow[t]{2}{*}{$\begin{array}{c}\text { Total } \\
\text { No. }\end{array}$} & \multirow[t]{2}{*}{$\begin{array}{l}\text { Listed in diss. } \\
\text { index }\end{array}$} & \multicolumn{2}{|c|}{$\begin{array}{c}\text { Listed only in catalogs } \\
\text { of secret dissertations at } \\
\text { Deutsche Bücherei, Leipzig }\end{array}$} \\
\hline & & & No. & $\%$ \\
\hline Berlin-Wartenberg & 45 & 31 & 14 & $31.1 \%$ \\
\hline Dresden & 103 & 95 & 8 & $7.8 \%$ \\
\hline Mittweida & 48 & 35 & 13 & $27.1 \%$ \\
\hline Warnemünde & 62 & 58 & 4 & $6.5 \%$ \\
\hline Wismar & 109 & 101 & 8 & $7.3 \%$ \\
\hline Zittau & 132 & 91 & 41 & $31.1 \%$ \\
\hline
\end{tabular}

(Source: Figures compiled from Jahresverzeichnis der Hochschulschriften (German dissertation index), 1978-1987 and accession catalogs of secret dissertations in the Deutsche Bücherei, Leipzig)

prisingly, lay below the national average. Nonetheless, one finds differences among the teachers colleges in their assignment of classifications. While the Teachers College in Potsdam, the largest such institution in the GDR, classified only thirteen of its dissertations between 1978 and 1987 as Level II, the Güstrow Teachers College, one-fourth its size, classified fourteen dissertations as secret. And at the ErfurtMühlhausen Teachers College only two dissertations were classified secret, both in 1979.

\section{Review of Secret Classifications}

The governmental resolution of January 15,1987 , on the protection of official state secrets led to a review of the levels of secrecy for all classified dissertations. This review produced some surprising results. In a letter addressed to the General Director of the Deutsche Bücherei on March 16,1988 , the Chancellor of the Zwickau Engineering College wrote, ". .. all the dissertations classified as Level I from the Zwickau Engineering College are immediately declassified and may be treated accordingly." In a letter of June 8, 1988, the Vice-Chancellor of the Engineering College at Wismar reported that all the dissertations from that institution designated Level I and held at the Deutsche Bücherei were immediately declassified. The Level I accession catalogs of the Deutsche Bücherei show that between February and September 1988 a total of 642 dissertations were declassified: 257 from Halle, 87 from Zwickau, 63 from Greifswald, 43 from Wismar, 144 from Rostock, and 48 from Ilmenau. In addition, the Academy of Sciences declassified 83 Level II dissertations in August. Thus, in the space of only seven months, more than 700 dissertations were declassified and made publicly available based on the January 1987 resolution.

Clearly, the large number of declassifications was due in part to the extremely 
broad interpretation of the guidelines for classification that had been in effect-this in spite of the fact that Section 4 of the "Regulations for the Archiving of University Dissertations with State Secrets" (1977) required, "at appropriate intervals," a review concerning "the continuation or the cancellation of the secret classifications." In actual practice, however, these universities and colleges took their good time to review classified material, seemingly because of the considerable costs involved. And only rarely were dissertations, such as the one from Halle in 1987 , assigned a date in advance for lifting the classification. The assumption of an uncritical attitude towards continuing the secret classifications is confirmed by reactions to isolated inquiries from the Deutsche Bücherei concerning longstanding classifications: very frequently such dissertations were declassified only in response to the queries from Leipzig.

Because there was hardly any reaction from the colleges and universities to the regulation of January 15, 1987, requiring the review of declassified dissertations, these institutions were asked by the Deutsche Bücherei in the summer of 1988 to take a position on the matter. As a result, most Level I and many Level II dissertations were finally declassified. They are all stamped "Canceled" and bear the date September 2, 1988.

All the remaining dissertations, particularly those classified Level II, were still formally secret until October 3, 1990, although as of November 1989 they were in fact available to users.

The last official declassifications in the Deutsche Bücherei occurred in March and April 1990 for two dissertations from the Zittau Engineering College. Table 6 shows that individual institutions differed greatly in declassifying dissertations, just as they had in classifying them.

The greatest number of declassified dissertations from secret categories is found at the Academy of Sciences and the Agricultural Academy, which had, respectively, declassified 85.7 percent and 50.9 percent of all secret dissertations by September 1988. With the exception of the University of Rostock, the universities were much slower to declassify than the

\section{TABLE 5}

SECRET DISSERTATIONS FROM SELECTED TEACHERS COLLEGES, 1978-1987

\begin{tabular}{lcccc}
\hline Institution & \multicolumn{4}{c}{ Dissertations } \\
\cline { 2 - 5 } & $\begin{array}{c}\text { Total } \\
\text { No. }\end{array}$ & $\begin{array}{c}\text { Listed in diss. } \\
\text { index }\end{array}$ & $\begin{array}{c}\text { Listed only in catalogs } \\
\text { of secret dissertations at } \\
\text { Deutsche Bücherei, Leipzig }\end{array}$ \\
\cline { 3 - 5 } & & & No. & $\%$ \\
\hline Dresden & 387 & 381 & 6 & $1.6 \%$ \\
Erfurt-Mühlhausen & 447 & 445 & 2 & $0.4 \%$ \\
Güstrow & 207 & 193 & 14 & $6.8 \%$ \\
Potsdam & 806 & 793 & 13 & $1.6 \%$
\end{tabular}

(Source: Figures compiled from Jahresverzeichnis der Hochschulschriften (German dissertation index), 1978-1987 and accession catalogs of secret dissertations in the Deutsche Bücherei, Leipzig) 


\begin{tabular}{|c|c|c|c|}
\hline DECLASSIFICATION & $\begin{array}{l}\text { BLE 6 } \\
\text { RTATION } \\
\text { TEMBER } 1\end{array}$ & TED & JTIONS \\
\hline \multirow[t]{3}{*}{ Institution } & \multicolumn{3}{|c|}{ Level II Dissertations } \\
\hline & \multirow[t]{2}{*}{ Total No. } & \multicolumn{2}{|c|}{ Declassified } \\
\hline & & No. & $\%$ \\
\hline Academy of Sciences & 105 & 90 & $85.7 \%$ \\
\hline Agricultural Academy & 220 & 112 & $50.9 \%$ \\
\hline Architectural Academy & 30 & 3 & $10.0 \%$ \\
\hline Medical Academy, Berlin & 44 & - & - \\
\hline Mining Academy, Freiberg & 152 & 12 & $7.9 \%$ \\
\hline Humboldt University, Berlin & 402 & 18 & $4.5 \%$ \\
\hline University of Greifswald & 79 & 7 & $8.9 \%$ \\
\hline University of Halle & 241 & 10 & $4.2 \%$ \\
\hline University of Jena & 99 & - & - \\
\hline University of Leipzig & 200 & 15 & $7.5 \%$ \\
\hline University of Rostock & 115 & 25 & $21.7 \%$ \\
\hline College of Economics, Berlin & 286 & 44 & $15.4 \%$ \\
\hline Commercial College, Leipzig & 67 & 33 & $49.3 \%$ \\
\hline \multicolumn{4}{|l|}{ Technical Schools } \\
\hline Ilmenau & 95 & 37 & $39.0 \%$ \\
\hline Karl-Marx-Stadt & 221 & 8 & $3.6 \%$ \\
\hline Leuna-Merseburg & 127 & 14 & $11.0 \%$ \\
\hline Magdeburg & 38 & 5 & $13.2 \%$ \\
\hline \multicolumn{4}{|l|}{ Engineering Colleges } \\
\hline Wismar & 8 & 4 & $50.0 \%$ \\
\hline Zittau & 41 & 4 & $9.8 \%$ \\
\hline Total & 2,869 & 460 & $16.0 \%$ \\
\hline
\end{tabular}

(Source: Figures compiled from accession catalogs of secret dissertations in Deutsche Bücherei, Leipzig)

academies. The Technical University of Karl-Marx-Stadt, for example, assigned secret classifications generously, but declassified them slowly. The Commercial College in Leipzig often assigned declassification dates to its Level II dis- sertations, whereas the opposite was true of the College of Economics in Berlin, which often not only took up to a decade to deliver its Level II dissertations to the Deutsche Bücherei, but also declassified hardly any. 


\section{Summary}

We can draw the following provisional conclusions from our interim report:

(1) In spite of the directions of the Ministry of Higher Education, the actual classification of dissertations was handled very differently by different institutions.

(2) The reasons for assigning classifications of secrecy to particular dissertations are to be found not only in their relevance to issues of state security or economics, but in the individual institution's academic self-perception and need for political prestige.
(3) Librarians could implement the procedures mandated by government and Party policy regarding secret dissertations only at great bureaucratic expense, and at the cost of their primary responsibilities, i.e., the development of collections accessible for research.

(4) It will surely take a number of years for libraries to overcome this inheritance from the GDR, that is, to integrate the secret dissertations into the general collections and the standard bibliographic tools.

\section{Postscript: Further, Still More Secret Dissertations}

\section{Lothar Mertens}

By 1994, as our research project was being concluded, almost 9,000 secret dissertations had been identified bibliographically (2,200 more than in 1992). Further, in addition to the two levels of secrecy described in the original article, two even more secret levels have been discovered.

\section{Additional Secret Classifications}

There were two higher levels of secret classifications of dissertations that could not even be held in the special stacks of the university libraries. Nor could they be forwarded to the Deutsche Bücherei in Leipzig. Rather, they were held in steel vaults by the central administration of the institutions at which they were written. Only a very small number of department heads and selected professors were permitted access to dissertations classified as Level III ("Confidential Matters"), and an even smaller number of selected highlevel administrators had access to dissertations classified as Level IV ("Top Secret Matters").

Obviously, as had been the case with Level I and Level II dissertations, such top secret dissertations were not listed in the German national bibliography, nor in the annual dissertation index.

The University of Greifswald and especially the College of Economics in Berlin assigned a relatively high proportion of dissertations to Levels III and IV (see table 7). In Greifswald, dissertations from the Department of Military Medicine were classified accordingly, while at the East Berlin College of Economics, dissertations were classified if they contained data from the Central Planning Commission, the National Central Agency for Statistics, or the state-owned armaments conglomerate. All the college's Level IV dissertations were written under the Department of Military Economy, which led a largely separate existence. The Department of Military Transport and Communications at Transportation College in Dresden, where almost all the college's Level III and IV dissertations were defended, was similarly isolated.

\section{Nonuniversity Ph.D.-Granting Institutions}

In addition to the universities and col- 
TABLE 7

SECRET DISSERTATIONS FROM SELECTED UNIVERSITIES

\begin{tabular}{|c|c|c|c|c|c|c|c|}
\hline \multirow[t]{2}{*}{ Institution } & \multicolumn{7}{|c|}{ Dissertations } \\
\hline & $\begin{array}{c}\text { Total } \\
\text { No. }\end{array}$ & $\begin{array}{c}\text { Listed } \\
\text { in diss. } \\
\text { index }\end{array}$ & $\begin{array}{l}\text { No. } \\
\text { classified } \\
\text { Level I }\end{array}$ & $\begin{array}{c}\text { No. } \\
\text { classified } \\
\text { Level II }\end{array}$ & $\begin{array}{c}\text { No. } \\
\text { classified } \\
\text { Level III }\end{array}$ & $\begin{array}{c}\text { No. } \\
\text { classified } \\
\text { Level IV }\end{array}$ & $\begin{array}{c}\% \\
\text { kept } \\
\text { secret }\end{array}$ \\
\hline Academy of Sciences & 1,535 & 1,326 & 103 & 105 & 1 & $\cdot$ & $13.6 \%$ \\
\hline Agricultural Academy & 637 & 377 & 40 & 220 & - & - & $40.8 \%$ \\
\hline Mining Academy, Freiberg & 984 & 599 & 176 & 152 & 57 & - & $39.1 \%$ \\
\hline Humboldt University, Berlin & 6,049 & 4,981 & 557 & 411 & 95 & 5 & $17.7 \%$ \\
\hline University of Greifswald & 1,283 & 1,123 & - & 79 & 59 & 22 & $12.5 \%$ \\
\hline University of Halle & 2,842 & 2,556 & 2 & 241 & 43 & $\cdot$ & $10.1 \%$ \\
\hline University of Jena & 1,993 & 1,804 & 78 & 99 & 12 & - & $9.5 \%$ \\
\hline University of Leipzig & 4,062 & 3,722 & 96 & 200 & 44 & $\cdot$ & $8.4 \%$ \\
\hline University of Rostock & 2,015 & 1,875 & 14 & 115 & 11 & - & $6.9 \%$ \\
\hline College of Economics, Berlin & 848 & 440 & 9 & 236 & 149 & 14 & $48.1 \%$ \\
\hline \multicolumn{8}{|l|}{ Technical Schools } \\
\hline Dresden & 3,294 & 3,052 & 183 & 49 & 10 & - & $7.3 \%$ \\
\hline Transportation College, Dresden & 629 & 426 & 132 & 38 & 22 & 11 & $32.3 \%$ \\
\hline Ilmenau & 795 & 588 & 95 & 95 & 17 & - & $26.0 \%$ \\
\hline Karl-Marx-Stadt & 1,329 & 1,029 & 75 & 221 & 2 & 2 & $22.6 \%$ \\
\hline Leuna-Merseburg & 1,005 & 512 & 364 & 127 & 2 & $\cdot$ & $49.1 \%$ \\
\hline Magdeburg & 859 & 751 & 57 & 38 & 13 & - & $12.6 \%$ \\
\hline
\end{tabular}

leges, educational institutes within the army, police, and national security services of the GDR also had the right to grant doctoral degrees, a fact left unmentioned in all governmental publications devoted to the subject of higher education in the GDR. Most of the 2,000-plus dissertations identified after the initial part of this study came from these institutions (see table 8).

The course of specialized studies at these institutions was comparable to that offered by the training schools ("Fachhochschulen") and cannot be compared to the offerings of a traditional university. The reason for the strict secrecy practiced there becomes clear upon examining the titles of their dissertations.

Organizations within the Socialist Unity Party that were responsible for educating its members and providing scientific expertise to the Party leadership also held the authority to grant doctoral degrees. They reported directly to the Party's Central Committee. With the exception of the Party Academy for the Social Sciences, which listed about half its dissertations in the annual dissertation index, the works of these Party and security services graduate institutions did not appear in the standard bibliographies. Even the Deutsche Bücherei, then the na- 
tional library of the GDR, does not own a single one of these dissertations written at military or Party institutions. These institutions did not forward any depository copies, even for works declassified to a lower level. Most of the dissertations written under the aegis of the National People's Army are, however, still in the Military Library at Dresden.

The National People's Army maintained a comprehensive educational system, which included eight additional colleges for noncommissioned officers and four colleges for career officers. Its principal school was the Military Academy in Dresden, founded in 1959. Here officers were trained for three to four years in subjects such as tactics, the leadership of troops, political activity, and military theory and doctrine. These studies concluded with either an examination or with graduation at the rank of Dr. rer. mil. (rerum militarium), an academic degree granted only in the GDR. Given this military emphasis, dissertations centered around topics such as military tactics, weaponry, and military history. Graduates of the four officers schools of the individual branches of the military (which did not have the authority to grant the doctoral degree) also received their doctorates from the Military Academy.

Military doctors for the National People's Army received their medical training at the Military Medical Academy at Bad Saarow in Mecklenburg, an offshoot of the Department of Military Medicine of the University of Greifswald. Military history was generally studied at the Military Historical Institute in Potsdam.

A special service rank, the Political Officer, corresponding to a position in the Soviet Red Army, was established for the political instruction of soldiers and noncommissioned officers in the National People's Army. This officer was not simply responsible for the troops' communist education, but he also served as the second-in-command to the Commanding Officer, acting as the Party's authority in the armed forces. Given the Political Officers' special role, it is not surprising that

\begin{tabular}{|c|c|c|c|c|c|c|c|}
\hline \multirow[t]{2}{*}{ Institution } & \multicolumn{7}{|c|}{ Dissertations } \\
\hline & $\begin{array}{c}\text { Total } \\
\text { No. }\end{array}$ & $\begin{array}{c}\text { Listed } \\
\text { in diss. } \\
\text { index }\end{array}$ & $\begin{array}{l}\text { No. } \\
\text { classified } \\
\text { Level I }\end{array}$ & $\begin{array}{c}\text { No. } \\
\text { classified } \\
\text { Level II }\end{array}$ & $\begin{array}{c}\text { No. } \\
\text { classified } \\
\text { Level III }\end{array}$ & $\begin{array}{c}\text { No. } \\
\text { classified } \\
\text { Level IV }\end{array}$ & $\begin{array}{c}\% \\
\text { kept } \\
\text { secret }\end{array}$ \\
\hline Security Police Legal College, Potsdam & 174 & $\cdot$ & 21 & 2 & 100 & 51 & $100.0 \%$ \\
\hline Military Medical Academy, Bad Saarow & 318 & - & 284 & - & 20 & 14 & $10.7 \%$ \\
\hline Military Academy, Dresden & 502 & - & 163 & $\cdot$ & 208 & 131 & $67.5 \%$ \\
\hline Military Political College, Berlin & 8 & $\cdot$ & 6 & - & 2 & $\cdot$ & $100.0 \%$ \\
\hline Military Historical Institute, Potsdam & 61 & - & 41 & - & 11 & 9 & $32.8 \%$ \\
\hline Police College, Berlin & 129 & - & 129 & $\cdot$ & 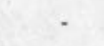 & - & $100.0 \%$ \\
\hline Party Academy for the Social Sciences & 903 & 295 & 261 & 303 & 43 & 1 & $67.3 \%$ \\
\hline Karl Marx College & 35 & - & 31 & 4 & - & - & $100.0 \%$ \\
\hline Institute for Marxism-Leninism & 80 & - & 62 & 18 & - & - & $100.0 \%$ \\
\hline Academy for Political \& Legal Science & 382 & 132 & 250 & - & - & - & $65.5 \%$ \\
\hline
\end{tabular}


they were trained separately from the other officers at the Military Political College in Berlin. If they didn't receive Level III or IV classifications, most of the dissertations written at these graduate military institutions were classified "For Use Only in the National People's Army," a classification comparable to Level II.

One of the least known graduate institutions in the GDR was the Police College in Berlin. Founded in 1962, it was granted the right to confer the Ph.D. in 1964. Secret dissertations of the People's Police include, among others, "The Regulation of Street Traffic from the Perspective of the German People's Police" and "The Guarantee of Public Order and Security Relating to International Soccer Matches and Soccer Leagues as Related to the Operations of the German People's Police."

Given the low scholarly relevance of such topics, it isn't surprising that in the twenty-five years from 1965 to 1990 only 129 dissertations were defended at the Police College. In 1993, after the college was dissolved, these dissertations were given to the library at Humboldt University in Berlin, where they are presently being added to the theses collection.

One of the smallest and most mysterious educational sites in the GDR was Potsdam's Security Police Legal College, which was founded in 1961. Only fulltime employees who had served at least three years in the National Security Service were sent there to study. Its program emphasized detailed mastery and proper interpretation of the service's countless guidelines, regulations, instructions, and orders. Approximately 760 instructors taught about 500 participants in three departments. While the departments of Marxist-Leninist studies and jurisprudence were comparable to similar programs elsewhere in the GDR, instruction in the Department of Political Strategy served to educate the "Promoters of Peace" (as the GDR spies were designated in Party jargon) in matters relating to their "strategic work."
Graduates of the Legal College could also seek the rank of "Dr. jur." (doctor of jurisprudence) upon the successful completion of their legal studies, since the college had been granted authority to confer doctoral degrees in 1968. Altogether 174 dissertations were written by 478 doctoral candidates at this institution, with up to eight authors per title for team dissertations. The dissertations at the Legal College reveal a peculiar expansion of jurisprudence into the areas of criminal justice, espionage, and intrastate repression. Such topics as "Criminal Border Crossing by Youths and Adults Studied Phenomenologically as well as in their Social and Psychological Determinism" or "The Political-Strategic Organization of Colleges in the Federal Republic of Germany and West Berlin" had little to do with legal issues.

The dissertations from the Legal College were not just secret; they were almost all classified under the most secret categories. Only twenty-five of the 174 dissertations were classified Level II, 100 were designated Level III, and 51 as Level IV. Today most of these dissertations are in the Berlin Archive for Documents of the National Security Service of the former GDR (the so-called Gauck Authority).

Similarly inaccessible were the publications of the educational institutions of the Socialist Unity Party, which were all formally subordinate to the Party's Central Committee. Their research consisted mainly of work commissioned for the Politbureau and for the Party's Central Committee secretariats. Thus the Central Committee's Academy for the Social Sciences, founded in 1951, functioned mainly as a think-tank that also zealously churned out dissertations.

Founded in 1946, the year of the coerced union of the German Communist Party and the Social Democratic Party, the Karl Marx College of the Central Committee of the Socialist Unity Party assumed responsibility for the ongoing process of instructing the leading Party cadre. 
The number of defended dissertations was correspondingly small. Presumably as a result of the 1972 law regulating the "protection of professional secrets," the annual index of German dissertations began with its volume 87 (1971) to list only "General Publications" of the Karl Marx College, thus excluding the dissertations.

The Institute for Marxism-Leninism, founded in 1947 as the Marx-Engels-Lenin Institute, was responsible for the preservation of orthodox Communist teaching and for maintaining a scholarly basis to its ideology. Although many dissertations were submitted there each year, the institute was not designated as a Ph.D.-granting institution in the 1970s and 1980s in the German dissertation index.

Only a very limited group of selected administrative cadres at these Partysponsored Ph.D.-granting institutions was allowed access to the dissertations classified as "Internal Party Material," which were held in the archives of these Party organizations rather than in libraries. Two-thirds (294) of the 574 dissertations not listed in the standard bibliographies were placed at the Party's Academy of the Social Sciences in this classification, which was similar to the Level II classification. Today all these dissertations are widely accessible in a library of a section of the Federal Archive in Berlin devoted to Party activity in the GDR, while the duplicates from the Academy of the Social Sciences, which were turned over to the library of the Humboldt University at the time of unification, are being stored (in a facility that was once a church) and have yet to be processed.

Another large source of unlisted dissertations is the Academy for Political and Legal Science, Potsdam, which was responsible for the instruction of administrative cadres. Two-thirds of its dissertations were not registered. After the dissolution of the academy under the Unification Treaty, its library, including the former secret dissertations, has become the Library for Law, Economics, and the Social Sciences, a branch of the university library of the newly founded University of Potsdam.

In closing, it should be recorded that, thanks to the circumspect activities of countless librarians and archivists, the majority of these almost 9,000 secret dissertations have been preserved and are available for use in libraries and archives. In most disciplines extensive work on the content of these secret dissertations still needs to be done, although they are already beginning to play a role in some research projects.

\section{Notes}

1. Wilhelm Bleek and Lothar Mertens, "Geheimgehaltene Dissertationen in der DDR," Zeitschrift für Bibliothekswesen und Bibliographie 39 (1992): 315-26; and Lothar Mertens, "Weitere, noch geheimere DDR-Dissertationen," Zeitschrift für Bibliothekswesen und Bibliographie 41 (1994): 304-11.

2. - DDR-Dissertationen: Promotionspraxis und Geheimhaltung von Doktorarbeiten im SEDStaat (Opladen, Germany: Westdeutscher Verlag, 1994).

3. - eds., Bibliographie der geheimen DDR-Dissertationen/Bibliography of Secret Dissertations in the German Democratic Republic (Munich, Germany: K.G. Saur, 1994). See also Hartwig Lohse's critical review in MITTEILUNGSBLATT, Verband der Bibliotheken des Landes NordrheinWestfalen, 45,1 (March 1995): 91-92. 


\section{New Additions to The Greenwood Library Management Collection}

\section{A Library Manager's Guide to the Physical Processing of Nonprint Materials}

\section{By Karen C. Driessen}

and Sheila A. Smyth

Sponsored by Online Audiovisual

Catalogers, Inc. (OLAC)

A unique contribution to library management, this book provides practical advice on making wise decisions about the physical processing of nonprint materials, such as videotapes, computer disks, three-dimensional artifacts, and graphic materials. By drawing on the expertise of librarians around the country, the authors have created an analytical and practical guide for making processing decisions and for carrying out the physical processing of nonprint items.

Greenwood Press. 1995. 272 pages.

0-313-27930-6. \$59.95

\section{Information Services for People with}

\section{Developmental Disabilities}

The Library Manager's Handbook Edited by Linda Lucas Walling and Marilyn M. Irwin

Developmental disabilities are the most numerous of disabilities, and they are exceptionally complex. This professional reference overviews developmental disabilities and examines the information needs of people with developmental disabilities. The volume provides practical advice to librarians and information professionals who must meet these information needs and gives special attention to the ramifications of the Americans with Disabilities Act for librarians.

Greenwood Press. 1995. 368 pages.

0-313-28780-5. $\$ 65.00$

\section{Video Acquisitions and Cataloging \\ A Handbook By James C. Scholtz}

No other book available covers the topic of videocassette acquisitions so completely. This professional reference gives special attention to problems unique to cataloging videocassettes within the electronic, on-line cataloging environment. The text provides ample theoretical discussion, along with practical examples of a variety of solutions.

Greenwood Press. 1995. 184 pages. 0-313-29345-7. \$55.00

\section{Also of Interest}

Where in the World to Learn

A Guide to Library and Information Science for International Education Advisers By Edward A. Riedinger

(The Greenwood Educators' Reference Collection)

Educational advisers around the world respond daily to numerous questions about study or research in the United States and other countries. In order to adequately address the growing volume of these crucial inquiries, advisers must begin to develop themselves as information professionals. To this end Where in the World to Learn gives international education advisers a solid grounding in library and information management. It is the first guide ever written to formulate advising in terms of the principles and practices of library and information science. From it advisers will learn how to acquire appropriate materials, organize them in a useful manner, and effectively meet the needs of their clients.

Greenwood Press. 1995. 176 pages.

0-313-28703-1. \$55.00

\section{(ID D GREENWOOD}

88 Post Road West, P.O. Box 5007, Westport, CT $06881-5007 \cdot(203) 226-3571$ • Office FAX (203) 222-1502 